\title{
Storytelling in Teacher Professional Development
}

\author{
Tracy Rosen
}

\begin{abstract}
Teacher voices hold weight for their colleagues. When teachers tell a story of a positive experience with technology (or other teaching tools or strategies), they are showing that it is possible. "Stories, particularly those that are concrete and readily identified with, are particularly powerful for transferring knowledge rich in tacit dimensions" (Swap, Leonard, Shields, \& Abrams, 2001, p. 105). When teachers share their stories with each other, they create a reality based on concrete possibility. This article will focus on how we use teacher stories and conversations in professional development (PD) to create positive realities for teaching and learning.
\end{abstract}

"The truth about stories is that that's all we are." (King, 2003, p. 32)

We are made of story. When we talk to each other, we tell each other stories about what we believe to be important and true (Boje, 1991). Talking to each other is how people think together (Wheatley, 2002), and it is through these stories and conversations that we can build our organizations together. Of course, the nature of the stories we choose to share has implications in this process, as Norum (2006) writes, "If we create our realities through how we talk about them and we have a choice to emphasize the positive or the negative, what we choose to emphasize matters" (p. 110). This article will focus on how we choose what to emphasize in teacher professional development (PD) and how we can use teacher stories and conversations to create positive realities for teaching and learning through meaningful integration of technology.

The stories that I tell over and over again are stories about teaching and learning, specifically about figuring out new pathways to learning when it is seemingly blocked.

Let me tell you a story.

In 2006, I was part of a differentiated instruction implementation team for a school system. We invited experts in to talk about it. We did multiple workshops and presentations at different schools on how and why to differentiate instruction. The teachers weren't following through though and so finally, we asked, why?

The answers were all pretty similar-ranging from different priorities to not enough time for planning. The response that stood out the most for me was that the teachers "got it" on a theoretical level, but couldn't imagine what it might look like in their classrooms.

As a result, I brought a group of teachers on a field trip to a classroom 168 kilometres away, in Burlington, Vermont, to see differentiation in action. Half-way through the morning of our visit, I looked over at my 
group of teachers and wondered what they were thinking. I couldn't read the expression on the face of one of the teachers, and I thought that he must have been thinking about all of the work he had to do to prepare for his substitute teacher in order to be away for the day. As the students filed out to recess, I asked him, trepidatiously, "So?" He paused, and then answered, "I think I learned more this morning than at my four years in Teacher College. I can't wait to get back to my classroom to try some of this out."

Fast forward to 2015, working for a different school system with a different focus - the integration of technology — but the context was strikingly similar: multiple workshops and presentations about how to use technology for learning with minimal impact on daily classroom practice. I work with the RECIT network and part of my job entails visiting teachers and adult education centres to see what they are doing with technology in their classrooms. Whenever I saw something great, I thought how wonderful it would be if we could do classroom-visit field trips so that teachers could experience firsthand their colleagues' innovative practices in the area of technology integration. Logistically, that can be difficult to organize with scheduling, traveling to distant regions of the province, and budgetary constraints. At the same time, the RECIT network was starting to look at ways we could offer our services virtually. So, effectively I was playing with two questions at the same time:

1. How can we organize classroom visits between teachers with all of the scheduling and budgetary constraints?

2. How can I offer virtual technology consulting services?

The answers to these two questions merged into the Teacher Story videos.

\section{Teacher Story Videos: Validating Teacher Experience by Listening to and Celebrating Their Stories}

So often we focus on what is not happening in the classroom-not enough technology, not enough collaboration, not enough "insert activity here." Borrowing from Appreciative Inquiry (AI), which focuses on the power of generative stories to bring about change through the passion and engagement that already exist in an organization (Cooperrider, 2002), I decided to consciously focus on what is happening in our classrooms. I decided to listen to our teachers' stories and to celebrate them by turning them into videos that could be shared with others. In this way, teachers could share each other's stories and visit each other's classrooms without having to worry about the logistics involved with physical visits.

Why the emphasis on teacher stories? I could have chosen to retell their stories in my own words. It would likely have been easier for me to stay in my office and do just that, rather than travel to different classrooms, record teachers, and then edit their recordings into bite-sized pieces. Teacher voices hold weight for their colleagues. When a teacher tells a story of a positive experience with technology (or any other teaching tool or strategy) he or she is showing that it is possible. "Stories, particularly those that are concrete and readily identified with, are particularly powerful for transferring knowledge rich in 
tacit dimensions" (Swap et al., 2001, p. 105). When teachers share their stories, they are creating a reality based on concrete possibility. Secondhand stories do not share that same possibility.

By the end of the 2016 school year, I had a collection of 14 teacher story videos, featuring teachers from across Quebec. I shared the videos in a YouTube playlist (http://bit.ly/TeacherStoryVideos) on social media, my blog (http://PdPractice.com) and on PD Mosaic (http://pdmosaic.com), an online professional development platform. I wanted to make sure that as many teachers as possible could access these stories and I was quite preoccupied with how to use these stories in as meaningful a way as possible (Rosen \& Spector, 2016). This question continued to roll around my mind for the next few months.

\section{Stories and Conversation: Using Care to Guide Us Through Change}

The children's television host Mr. Rogers always carried in his wallet a quote from a social worker that said, "Frankly, there isn't anyone you couldn't learn to love once you've heard their story." And the way I like to interpret that is probably the greatest story commandment, which is, "Make me care." - please, emotionally, intellectually, aesthetically, just make me care." (Stanton, 2012)

Let me tell you a story.

A few months before our trip to Burlington in 2006, a colleague and I were asked to give a presentation on differentiated instruction to a group of teachers in one elementary school. The presentation took place at four in the afternoon, after a full day of teaching, and there were about 50 teachers crammed behind student desks in the classroom where we presented. So, we started our presentation with some theory about why they should differentiate their instruction and progressively moved on towards some advice on how they should go about doing so. At one point, as my colleague was speaking, I looked around the room and saw a group of tired, skeptical-even angry-teachers. Some of the less tired teachers were arguing with my colleague about how differentiated instruction was nice in theory, but it couldn't possibly work in their classrooms, with their students. I realized that the theory we were presenting was missing something. I interrupted my colleague and we shifted gears. We shifted the conversation away from the theory and towards the teachers in the room. I asked them to turn to each other and tell each other their stories about how and why they became teachers. Gradually, over a series of meetings over the next little while, the teachers were given the opportunity to talk with each other about their dreams for their students as well as stories of success that were already happening in their classrooms. As the teachers shared their stories, they moved towards concrete possibility.

What was it that had been missing from our presentation of theory? It was Andrew Stanton's greatest story commandment-make me care. By sharing their stories of hope, dream, and success, the teachers were effectively building their realities on hope, dreams, and success. This process brought them to want to learn more about differentiated instruction in order to help them realize these hopes, dreams, and successes. It was their own stories that made them care-not our presentation of theory about why they should care. 
Fast forward to 2015, we were working with a different group of teachers with a different focus, but the context was similar. My colleague, Avi Spector, and I were invited to an adult centre to present about using stations as a teaching strategy in adult education. We presented to about 10 teachers at two in the afternoon, after a full day of teaching. We proceeded to present some theory and to talk about the different reasons we thought they should teach in stations. As the afternoon progressed, we both felt the energy waning in the room. A couple of teachers left before the end of the presentation. As soon as it was over we turned to each other and said, "Why were we talking at them about stations? Why didn't we let them experience stations together?"

Once again, I was at a point in my own practice where I was playing with two questions at the same time. Avi and I asked each other:

1. How can we best share the teacher story videos with other teachers?

2. How can we design authentic professional development (PD) opportunities about using stations as a teaching and learning strategy to better integrate technology?

Once again, the answers to our questions merged together and changed our practice.

\section{Sharing Teacher Stories in Professional Development}

"Conversation is the natural way we humans think together" (Wheatley, 2002, pp. 42-43)

In April of 2016, Avi and I had the opportunity to design a large-scale workshop in stations at the annual conference of I'Association Québécoise des Intervenants et Intervenantes en Formation Générale des Adultes (AQIFGA). Instead of presenting about stations, we were going to allow our participants to experience stations.

At roughly the same time I was working with Emilie, a teacher at an adult education centre, as she started to use stations in her classroom. At the end of our process, I recorded a conversation we had about teaching in stations with adult learners, thinking that I would create a teacher story video once the AQIFGA conference was over.

Both Avi and I wanted to model an effective use of video during our stations workshop at AQIFGA. As we got closer to the conference date, we discovered that it was difficult to find videos about stations that were appropriate for adult educators. Finally, I realized that we had our videos; they just weren't put together yet. So, with less than a week until the conference, I put everything else on hold and created a series of videos about Emilie's experience with stations and we designed a simple activity around them to use at one of our stations (See Figures 1 and 2). 


\section{Video Station}

Learning Target:

Deepen understanding of stations

1. Watch the videos at bit.ly/videostation with headphones on.

2. Answer the two questions with the paper provided.

Fig. 1: Video station instruction card used at AQIFGA 2016

\section{Describe your thoughts on stations.}

\section{How do you see using stations in your classroom?}

Fig. 2: Video station questions used at AQIFGA 2016

The stations workshop was a success. Teachers were actively involved in their learning as they rotated through the three stations: a video station, a reading station, and a teacher station (see Figure 3). It was important for us to model strategies that could easily be transferred to the classroom, so we also had an extension station where participants could access other resources if they finished an activity early. 


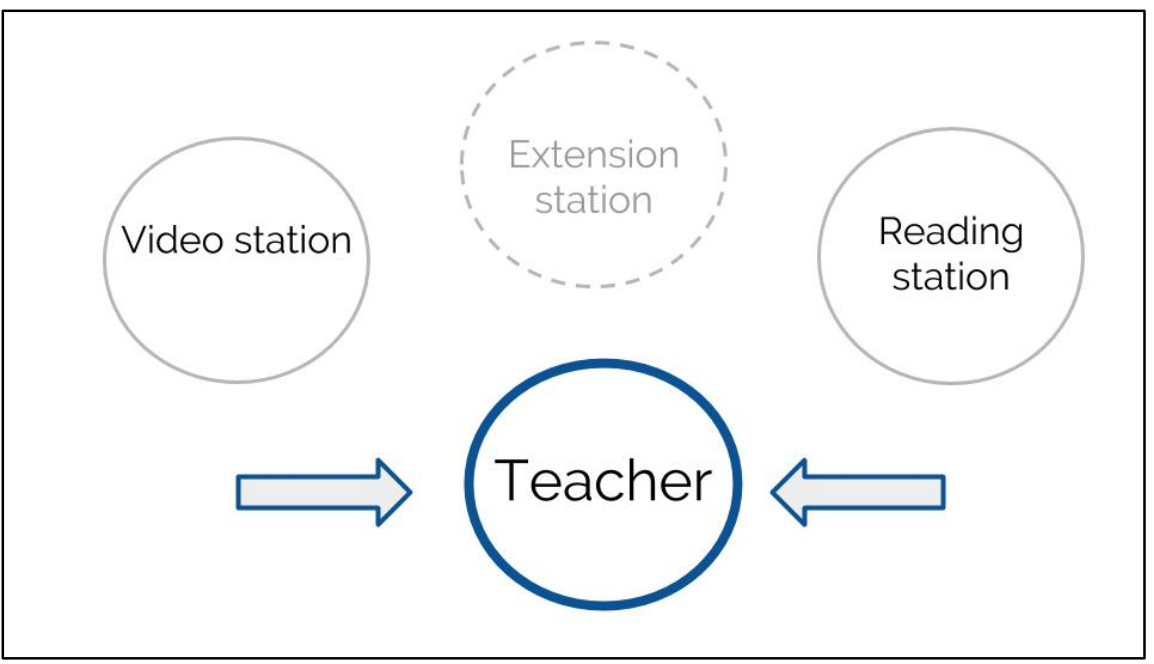

Fig. 3: Station configuration at AQIFGA 2016

A highlight for us, as presenters, was the teacher station where we facilitated a conversation between participants around the subject of using stations in adult education. As facilitators, we were able to stay at the teacher station because of the detailed instruction cards (see Figures 4-7) we left at each of the stations, as well as the ground rules we set up, which included the proviso: help each other (see Figure 8).

\section{Reading Station}

\section{Learning Target:}

Finding out what others think about stations.

1. Choose an article from the table to read.

2. Interview a partner using the guiding questions (each person should have a chance to be interviewed).

Note: This is a collaborative activity, meant to be done in pairs or small groups. Be mindful of the volume of your voice. Thank you.

Fig. 4: Reading station instruction card from AQIFGA 2016 


\section{Video Station}

Learning Target:

Deepen understanding of stations

1. Watch the videos at bit.ly/videostation with headphones on.

2. Answer the two questions with the paper provided.

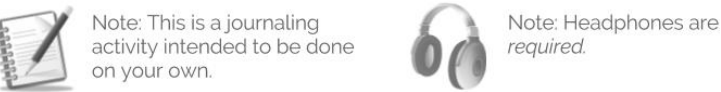

Fig. 5: Video station instruction card from AQIFGA 2016

\section{Extension Station}

Learning Target:

Self-guided learning about stations

1. Explore resources of your choice. This is your time to find out what's important to YOU. (i.e. - planning, Internet research, etc.)

2. If you need a starting point, take a look at Khan Academy on blended learning:

https://wwww.khanacademy.org/partner-content/ssf-cci

Note: Headphones are required if you are

watching videos. Thank you.

Fig. 6: Extension station instruction card from AQIFGA 2016

\section{Teacher Station}

Learning Target:

Clarifying and answering questions around stations

1. Ask questions!

Note: This is a collaborative activity. Be

mindful of the volume of your voice for

the other stations. Thank you.

Fig. 7: Teacher station instruction card from AQIFGA 2016 


\section{Ground rules:}

- We will use a timer to rotate

- Headphones for videos

- Be mindful of your voice/volume

- Help each other

Fig. 8: Ground rules posted in the room at AQIFGA 2016

Traditional workshops are about the presenter's story. This workshop became about the teacher stories. As they listened to each other and heard the stories of possibility, teachers were inspired to take risks and to effectively build their own new realities. As a result of this workshop, we created three new teacher stories based on participants who went on to use stations in their classrooms. Some of those teachers are now ambassadors who teach other teachers about using stations and other similar strategies in adult education (Rosen, 2017).

\section{Transmedia Storytelling: Teacher Story Videos Are Only One Part of the Story}

When teachers share their stories in a public way through video, they are helping to create a practice that encourages risk-taking. When used in PD, the videos generate conversations that help to form a sense of connection between the participants and, in turn, help them to tell their own stories about issues they may not have talked about otherwise. The stories and conversations help teachers to make sense of what they are learning together (Haigh \& Hardy, 2011).

Professional development in stations provides an authentic way for us to integrate the teacher story videos into our practice. But the story doesn't end there. The teacher story videos are one piece of the story of professional learning. The activities at each of the stations are intentionally designed to help create a larger story of learning and practice. This is where the facilitator's role in the storytelling process comes into play.

Transmedia storytelling is the idea that we can access a story across multiple platforms in a nonlinear manner (Rodrigues \& Bidarra, 2014). In order to make us want to access a story to begin with, Rodrigues and Bidarra explain that a learning experience "...must be engaging, encourage collaboration, [and] develop creative thinking and problem solving skills" (p. 47). The facilitator's role, therefore, is in the careful design of professional learning opportunities so that participants can have access to and participate in the sharing of stories. 
Professional development that uses a stations approach is a strategy for transmedia storytelling in itself. When each station is designed to allow access to the same subject in a unique way, participants are able to participate in the storytelling in diverse ways, thus allowing a greater number of participants to identify with their professional development activities than if there was only one way to participate.

Fast forward to 2018

In organizations, the questions we ask determine the stories we tell, and these stories, in turn, directly and significantly influence our levels of optimism and energy to engage in constructive action... when our inquiry focuses on the very best of the past and the most promising potentials for the future, our stories become increasingly inviting and encouraging, and our energy for action expands. (Ludema, 2002, p. 259)

Two years after our first workshop in stations, we continue to refine how we structure the stations we use. It is an iterative process, based on feedback from participants. The essential elements are the same, however: a handful of stations, instruction cards at each station, and opportunities for dialogue and reflection with meaningful integration of technology. All of these elements help to structure opportunities for sharing stories based on the good that is already happening in our schools, centers, and classrooms. Through these stories and conversations, teachers discover what it is they truly care about.

Trust is another essential element. As facilitators, we need to trust that our participants will talk about what is important to them. We also need to trust that what is important to them is what needs to be talked about. Khalsa (2002) describes trust as a "...huge factor in creating an organization that everyone feels ownership in" (p. 237).

When designing our workshops, we purposely stay away from questions about obstacles or barriers to learning and change. This is another instance borrowed from Appreciative Inquiry (AI). It is not that we ignore the problems, we want to encourage participants to look at them from the other side: the side of hope, the side of what has already worked and then plan to create more instances of this (Cooperrider \& Whitney, 2001). Bushe (2007) talks about this as not so much a focus on the positive as a focus on the generative power of sharing our stories of what already works:

Actually, $\mathrm{Al}$ is different because it focuses on generativity instead of problem-solving. Without common problems and issues people don't create transformational change. Instead of trying to solve the problem, Al generates a collective agreement about what people want to do together and enough structure and energy to mobilize action in the service of those agreements. When that happens, many "problems" get "solved". (p. 7)

The latest workshop Avi and I designed together was on January 11, 2018 (as of the submission of this article on February 1, 2018). We were invited to work with the continuing education community of one school board for a whole day on the subject of flexible learning environments for adult learners. Amongst the participants were the administrators of the different centers at the board. The morning was organized through stations, and the afternoon, through structured conversations to begin planning classroom changes. We gave the participants a planning guide (http://bit.ly/qcspaceplanningframeworks) as a way to structure the afternoon's conversations and to take notes during the morning's activities. 
Again, the focus was on teacher stories of what they were already doing in their practice and we trusted them to work together to help each other create more instances of what they identified as successful teaching and learning practice. Our job was to frame these conversations so that, together, they served as multiple access points to the story of teaching and learning in their school board.

We had five stations:

- A design station, where participants designed a space based on specific criteria and were prompted to have conversations about their design intentions. They used furniture and technology that we provided at the station.

- A presentation station, where participants guided themselves through a slideshow of different classroom examples of flexible learning spaces in Quebec and were prompted to talk about what they saw in relation to their own classrooms and centers.

- A flipgrid station, where participants were invited to reflect on the question, "how does teaching change when we change our spaces?" and then record their answers at http://flipgrid.com for others to respond to.

- A resource station, where participants were invited to read a selection of resources and then to fill out a KWL chart based on a group conversation about what they already know, what they want to learn, and what they are learning about Universal Design for Learning (UDL) and flexible learning environments.

- A teacher station, where Avi and I facilitated conversations with participants around the question, "how does our teaching change with UDL and flexible classrooms?"

Each of the stations had an instruction card to guide the participants through the learning process (see Figures 9-13).

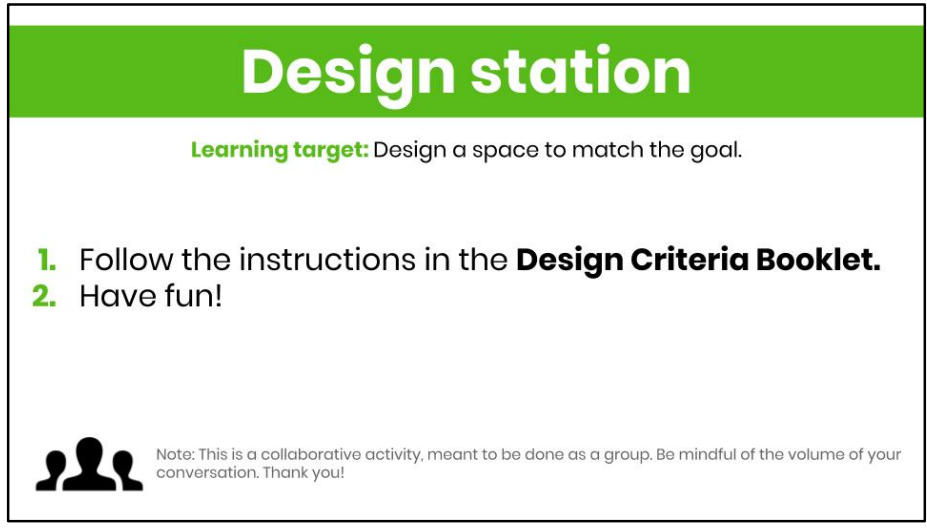

Fig. 9: Design station instruction card, January 2018 


\section{Presentation station}

Learning targets: Talk about how teachers in Quebec are designing their rooms. Gather information for your planning proposals

1. View the presentation with your group at bit.ly/wqsbpres

2. Talk about what you see in relation to your own classes, programs, and students.

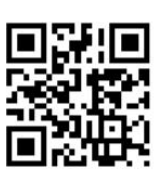

3. Take notes in your planning guide.

Note: This is a collaborative activity, meant to be done as a group. Be mindful of the volume of your
conversation. Thank you!

Fig. 10: Presentation station instruction card, January 2018

\section{Flipgrid station}

Learning target: reflect on how practice changes when we change the space.

1. Download flipgrid on your device or go to flipgrid.com on your computer

2. Enter GRID CODE $\mathbf{9 0 8 9 2 2}$ and follow the instructions

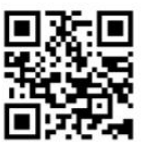

Note: This is a station for individual listening and speaking. You

may want to find a quiet place somewhere to complete the task.

Fig. 11: Flipgrid station instruction card, January 2018

\section{PD Moscic station}

Learning target: Deepen your group's understanding about UDL $\&$ learning environments.

1. Fill in the 1st two columns of the KWL chart.

2. Explore the resources at this site with your group: bit.ly/udiflexoverview

3. Continue filling in your KWL chart.

Fig. 12: Resource station instruction card, January 2018 


\section{Teacher station}

Learning target: Ask and answer questions about UDL \& your learning environments.

1. Conversation topic: How does our teaching change with UDL \& flexible classrooms?

2. Take notes in your planning booklet.

Fig. 13: Teacher station instruction card, January 2018

The participants had about 20 minutes per station with a minute in between each station to allow for a bit of reflection time. Participants could use this time to take notes in their planning guide to be used for the afternoon's planning session or simply to transition to the next station. We asked the participants to create their own groups for the morning, making sure to work with people from other centres with whom they don't usually work.

After lunch, they shifted into centre teams in order to facilitate planning for concrete change in their classrooms and centers. We asked them to begin working through their planning guide and then to join with another team to get feedback on their ideas.

Throughout the day's activities, participants shared their stories of teaching and learning around the topic of UDL and flexible classroom spaces. Our role as facilitators was in structuring the activities to encourage our participants to talk about what already works so that they could build on each other's energies in order to create more of it. We did this by creating multiple access points to the story of UDL and flexible classroom spaces in adult education.

Including the Teacher Story Videos I wrote of earlier within our stations workshops, as opposed to just keeping them online, is an important part of this process. Dalkir and Wiseman (2004) write about the importance of hearing stories,

...stories are also best experienced orally. They lose much of their effectiveness when simply read as a text, and they lose even more of their effectiveness when the target audience is a virtually distributed community where stories are simply posted to a shared work space. (p. 70)

By creating a structure for talking about the teacher story videos within the workshop, in this case through the KWL chart activity, we were able to bring outside experience into the room through story. Participants were confronted with concrete stories about practice in other adult education centers and were able to fold these stories into their own stories of teaching and learning.

I must stress the importance of the administrators' presence during this day. An important part of sharing stories to generate change is what we do with them after they are told. 
Leaders can "...ride a wave of positive change..." (Van Buskirk, 2002, p. 97) generated by the appreciative images shared through their teachers' stories. It would be a shame to ask teachers to talk about their hopes and dreams for teaching and learning if nothing were to be done about them after the fact. Listening to teachers' stories validates their expertise as professionals; acting on what they have to say respects their expertise as well as the time they take to share their stories (Rosen \& Spector, 2016). Indeed, Bushe (2007) points out that one of the best predictors of the success of an Al initiative in education is the quality of school leadership (p. 7).

\section{Conclusion: The Power of Learning From Each Other Through Our Stories}

"There is no power equal to a community discovering what it cares about." (Wheatley, 2002, p. 22)

In adult education in Quebec, we are currently witnessing the power of storytelling in professional development. I began this article with four important questions:

1. How can we organize classroom visits between teachers with all of the scheduling and budgetary constraints?

2. How can I offer virtual technology consulting services?

3. How can we best share the Teacher Story Videos with other teachers?

4. How can we design authentic professional development (PD) opportunities about using stations as a teaching and learning strategy to better integrate technology?

The teacher story videos help to solve the first two questions by providing virtual visits to classrooms that are doing innovative things with technology. The next two questions are addressed by using the teacher story videos in PD and by consciously designing teacher PD that allows for multiple access points to stories around teaching and learning, such as with the idea of transmedia storytelling.

The kinds of PD opportunities described in this article call for an implicit use of technology as teachers use a variety of tools to share their stories and learn together. Anecdotally, we are seeing and hearing about how participants in these PD opportunities are subsequently using technology more often in their classrooms (Rosen \& Spector, 2016; Rosen, 2017). Further study is necessary to see if there is a direct relationship between technology use in professional development and its use in the classroom.

"Looking at the history of storytelling in organizations; stories have always been utilized; albeit not necessarily as a 'business or organizational tool'" (Kowalewski, 2013, p. 51). By explicitly incorporating storytelling into PD, Avi Spector and I are using story as a tool for individual and organizational learning. Storytelling works because it connects us to why we do what we do. We search for ways "... narrative can replicate our complex emotional, psychological, and intellectual experience" (Turchi, 2010, p. 19) and we use these stories to help us both make sense of our reality and to create positive new versions of it.

PD in stations is not the only way to design professional learning that harnesses the power of storytelling. Conversation-based professional development can take many forms, such as EdCamps, which is participant-driven PD that focuses on teacher conversation about what matters to them in education 
(Rosen \& Spector, 2017). The key to effective conversation-based professional development is in what we do with the stories that are shared in the conversations. A workshop that invites teachers to share their stories about what matters to them is but one part of a bigger story of change that school leaders will need to negotiate in order to see that change happen.

Thomas King wrote that the truth about stories is that that's all we are. He also wrote that we are as responsible for the stories we hear as for the stories we tell, because once you hear a story, it can't be called back (King, 2003).

I just told how one key to change in education is through storytelling.

You've heard it now. Do with it what you will.

\section{Author Note}

All images in this manuscript were developed by Tracy Rosen and Avi Spector and are licensed under a Creative Commons Attribution-ShareAlike 4.0 International License.

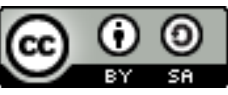

\section{References}

Boje, D. (1991). The storytelling organization: A study of story performance in an office-supply firm. Administrative Science Quarterly, 36(1), 106-126. Retrieved from http://dx.doi.org/10.2307/2393432

Bushe, G. R. (2007). Appreciative inquiry is not (just) about the positive. OD Practitioner, 39(4), 30-35. Retrieved from http://www.gervasebushe.ca/AI_pos.pdf

Cooperrider, D. (2002). Foreword: The coming epidemic of positive change. In R. Fry, F. Barrett, J. Seiling \& D. Whitney (Eds.), Appreciative inquiry and organizational transformation: Reports from the field (pp. vii-xi). Westport, CT: Quorum Books.

Cooperrider, D. L., \& Whitney, D. (2001). A positive revolution in change: Appreciative inquiry. Public Administration and Public Policy, 87, 611-630.

Dalkir, K., \& Wiseman, E. (2004). Organizational storytelling and knowledge management: A survey. Storytelling, Self, Society, 1(1), 57-70.

Fry, R., Barrett, F., Seiling, J., \& Whitney, D. (2002). Appreciative inquiry and organizational transformation. Westport, CT: Quorum Books.

Haigh, C., \& Hardy, P. (2011). Tell me a story - A conceptual exploration of storytelling in healthcare education. Nurse Education Today, 31(4), 408-411 Retrieved from http://dx.doi.org/10.1016/j.nedt.2010.08.001 
Khalsa, G. S. (2002). The appreciative summit: The birth of the United Religions Initiative. In R. Fry, F. Barrett, J. Seiling, \& D. Whitney (Eds.), Appreciative inquiry and organizational transformation: Reports from the field (pp. 211-238). Westport, CT: Quorum Books.

King, T. (2003). The truth about stories. New York, NY: House of Anansi Press.

Kowalewski, S. J. (2013). Storytelling: An integral facet in organizations. International Journal of Business and Social Research, 3(3), 51-54.

Retrieved from https://thejournalofbusiness.org/index.php/site/article/view/55/54.

Ludema, J. D. (2002). Appreciative storytelling: A narrative approach to organizational development and change. In R. Fry, F. Barrett, J. Seiling, \& D. Whitney (Eds.), Appreciative inquiry and organizational transformation: Reports from the field (pp. 239-262). Westport, CT: Quorum Books.

Norum, K. (2006). Stories to transform, not shatter: Mr. Peabody's advice for organizations. Storytelling. Self, Society, 2(2), 106-120.

Rodrigues, P., \& Bidarra, J. (2014). Transmedia storytelling and the creation of a converging space of educational practices. International Journal of Emerging Technologies in Learning, 9(6), 42-48. Retrieved from http://dx.doi.org/10.3991/ijet.v9i6.4134

Rosen, T. (2017). Technology and empathy: Unlocking access to resources in Session "Emballez-moi » des RDV du RÉCIT. Retrieved from https://youtu.be/qZhOH9cbMcY?t=39m

Rosen, T., \& Spector, A. (2016). Highlighting teacher voice with video + PD. Retrieved from https://youtu.be/JKzrAKZvLOg

Rosen, T., \& Spector, A. (2017). Bringing edcamp home. PD Mosaic. Retrieved from http://pdmosaic.com/index.php/home/tile/c879dc7e4f77336ac44491ed14f3e5ff

Stanton, A. (2012, February). Andrew Stanton: The clues to a great story. [Video file]. Retrieved from https://www.ted.com/talks/andrew_stanton_the_clues_to_a_great_story

Swap, W., Leonard, D., Shields, M., \& Abrams, L. (2001). Using mentoring and storytelling to transfer knowledge in the workplace. Journal of Management Information Systems, 18(1), 95-114. Retrieved from http://dx.doi.org/10.1080/07421222.2001.11045668

Turchi, P. (2010). New tools, new vision: Telling the next story. Lo Squaderno, 5(15), 17-20.

Retrieved from http://www.losquaderno.professionaldreamers.net/wp-

content/uploads/2010/02/losquaderno15.pdf\#page=17

Van Buskirk, W. (2002). Appreciating appreciative inquiry in the urban Catholic school. In R. Fry, F. Barrett, J. Seiling, \& D. Whitney (Eds.), Appreciative inquiry and organizational transformation: Reports from the field. Westport, CT: Quorum Books.

Wheatley, M. (2002). Turning to one another: Simple conversations to restore hope to the future. San Francisco, CA: Berrett-Koehler. 


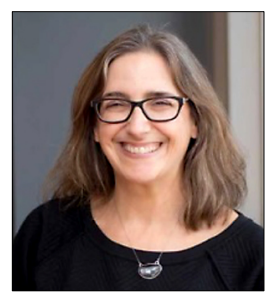

Tracy Rosen is an education consultant with the Commission scolaire de la Seigneuriedes-Mille-Îles and a Provincial resource person with the RECIT, Quebec's technology integration resource network. She believes that technology is best used when it helps to share our stories around teaching and learning and that if we want to see change in our classrooms, we need to see it in our professional development as well. She has taught in both the youth and adult sectors since 1996, and has an MA in Human Systems Intervention (2006) from Concordia University. 